\title{
La reina Mab: patrón arquetípico de la poética dariana
}

\author{
Mariam BOURHAN EL DIN \\ Universidad de El Cairo
}

\section{RESUMEN}

La reina Mab es una de las primeras figuras míticas que aparecen en la obra de Darío. Mab y el mundo de las hadas presenta un primer modelo de los motivos formales y conceptuales que definen el estilo de Darío. Desde sus primeras apariciones en La copa de las hadas y El velo de la reina Mab, el hada Mab se establece como leitmotiv que pregona el concepto modernista del arte a la vez que revela cómo Darío creó y desarrolló su original poética.

Palabras clave: reina Mab, hadas, Darío, Shakespeare.

\section{Queen Mab: archetypal pattern of Dario's poetics}

\begin{abstract}
Queen Mab is one of the first mythical figures to appear in the works of Dario. Mab and the world of fairies present an early model of formal and conceptual motifs that define Dario's style. Ever since she first appeared in La copa de las hadas and El velo de la reina Mab, the fairy queen became a leitmotiv that forecasts the modernist concept of art and reveals how Dario created and developed his unique poetics.
\end{abstract}

Key words: Queen Mab, Fairies, Darío, Shakespeare.

En El velo de la reina Mab, sí, mi imaginación encontró asunto apropiado. R. Darío, Historia de mis libros

Darío encuentra "asunto apropiado" en el mundo de las hadas. Las imágenes gráficas con las que el autor recrea el mito del hada $\mathrm{Mab}^{1}$ y presenta el mundo de las hadas sólo tiene su igual en las descripciones -también gráficas y agudamente

\footnotetext{
${ }^{1}$ Mab es el hada de los sueños que brinda a los soñadores visones de sus más anhelados deseos. Críticos y estudiosos desconocen las definitivas raíces mitológicas de Mab pero se ponen de acuerdo en que es un mito anglosajón pagano. Algunos afirman su origen celta (del vocablo irlandés Medb o del galés Mabb). También se le ha comparado con Mara, del folklore escandinavo, que también tiene el poder de visitar a los hombres en sueños.
} 
poéticas- de Shakespeare, la fuente original de inspiración de Darío a la hora de recrear ese mundo. En Historia de mis libros, Darío afirma que "El deslumbramiento shakespeareano me poseyó y realicé por primera vez el poema en prosa. Más que en ninguna de mis tentativas, en ésta perseguí el ritmo y la sonoridad verbales, la transposición musical"2. El comentario revela la influencia de Shakespeare a más de un nivel. Primeramente, a nivel formal, en las imágenes gráficas y la musicalidad que caracterizan las descripciones shakespeareanas, y en la figura misma del hada, minúscula, delicada pero con los poderes mágicos -es el hada de los sueños- que la convierten en tema atractivo para los artistas. Darío no es una excepción: encuentra en la imagen shakespeareana del hada un tema idóneo para dar rienda suelta a los juegos simbólicos, las imágenes plásticas y las descripciones sensoriales en que se basa su poética. A nivel conceptual, las hadas son la personificación del ideal dariano: son criaturas mágicas y exquisitas y sus vidas están dedicadas al placer y a la belleza. Estas características acercan a Mab al gran tópico dariano del arte y el artista en búsqueda del ideal que no existe en la realidad pero adopta las formas de la belleza de la mujer y del amor, según los cánones de la mitología clásica o las esculturas (también casi siempre clásicas) o los cuadros de Watteau, para citar unos ejemplos de la vasta gama de referencias artísticas presentes en la obra de Darío. Todos sirven el ideal de belleza y placer. Darío incorpora a Mab para inspirar ese ideal imposible que busca el artista. En esa conexión entre belleza, placer y arte, Mab es el preludio al cisne wagneriano, los mitos inspirados en Goya o incluso los más tempranos y explícitos cuadros exóticos de Las Mil y Una Noches. La elección del hada Mab como protagonista de unos de sus primeros poemas y cuentos ( $L a$ copa de las hadas y El velo de la Reina Mab), anuncia el particular (re)proceso dariano de determinados motivos (Leda, Orfeo, Venus, Pan, sátiros, centauros, cisne, azul, rubio, Shakespeare, Wagner, Watteau, Goya, Cervantes) que se acumulan, se entremezclan y se reinventan en una simbología que responde al concepto dariano de la escritura imaginativa.

De sobra se conoce la idea de una prosa castellana en crisis que Darío busca renovar ${ }^{3}$, primeramente a través de la influencia de los autores franceses que él describe, en Historia de mis libros, como "una mina literaria para explotar" (PE: 200). Pero no se trata únicamente de la crisis, que efectivamente existía, sino de la personalidad y las inclinaciones estéticas del propio Darío, manifiestas, desde una edad

${ }^{2}$ En R. Darío, Páginas escogidas, edición de Ricardo Gullón, Madrid, Cátedra 1982; el capítulo dedicado a Historia de mis libros, pp.197-225; 203-204. Subsiguientes citas de este libro se harán de esta edición y se indicarán con PE y el número de página. Darío cita a Shakespeare en más de una ocasión; en esta, Darío comentaba El velo de la reina Mab.

3 "Rubén Darío fue un gran elefante sonoro que rompió todos los cristales de una época del idioma español para que entrara en su ámbito el aire del mundo. Y entró", Neruda en Confieso que he vivido, Barcelona: Plaza \& Janés 1998; p. 341. 
temprana, en su fascinación por la estética literaria francesa y una auténtica y arraigada idolatría de París ${ }^{4}$. Esto, con un natural y agudo rechazo de todo lo mediocre y cotidiano ("la vida y el tiempo en que me tocó vivir"). Sus inclinaciones estéticas, entonces, se formulan desde muy joven, incluso antes de $\mathrm{Azul}^{6}$. Pero tradicionalmente, se suele citar a $A z u l$-prueba de su genio de poeta propuesto a renovar el lenguaje poético- como el inicial baremo de la subsiguiente producción literaria modernista española e hispanoamericana. Su poética se satura del culto simbolista (alusiones y sensaciones), de los principios parnasianos del arte por el arte y del cosmopolitismo lingüístico y literario, sin perder su identidad hispana que protagonizará sobre todo los Cantos de vida y esperanza. Darío forjará una creación artística, fundada en la defensa del arte de lo bello y la búsqueda de un ideal ajeno a la realidad y que más tarde les ganará a los modernistas el acusatorio apelativo de escapistas. Pero a finales del siglo XIX y comienzos del XX, las sociedades de Europa y, subsiguientemente, del mundo entero, sufren cambios definitivos que marcarán sus pueblos para siempre. La aparición del modernismo en ese tiempo no es arbitrario y sus características los son porque reflejan una actitud no solamente literaria, como mera reacción al romanticismo, sino de voluntad, ante la situación cambiante de la humanidad. Los modernistas actúan instigados por los sucesivos y rápidos cambios que les tocó vivir. Su actitud pretende lo que ya pretendía el famoso personaje cervantino pero mientras Don Quijote parte de una firme convicción en la cultura y se vuelca en la realidad aplicando la cultura como signo definitivo de ésta (los libros de caballerías son signos denotativos de la realidad; la realidad deberá ser como la denotan estos signos), los modernistas buscan reinterpretar los signos; la torre de marfil se manifiesta de espaldas a una realidad que no concuerda con los signos y se vuelca en espacios mágicos, majestuosos, exóticos, de épocas remotas, a

4 "Yo soñaba con París, desde niño. Al punto de que cuando hacía mis oraciones rogaba a Dios que no me dejase morir sin conocer Paris. París era para mí como un paraíso en donde se respirase la esencia de la felicidad sobre la tierra. Era la ciudad del Arte, de la Belleza y de la Gloria: y, sobre todo, era la capital del Amor, el reino del Ensueño", en R. Darío, Rubén Dario Esencial, edición de Arturo Ramoneda. Madrid, Taurus, 1991; en el capítulo que recoge pasajes de La vida de Rubén Dario escrita por él mismo, pp. 39-76; p. 63.

${ }^{5}$ Rubén Darío, Prosas profanas y otros poemas, edición de Ignacio M. Zuleta; Madrid, Castalia 1987; p.86. Citas de este libro se indicarán con PP y el número de página.

${ }^{6}$ Aquí dos ejemplos: A las orillas del Rhin, su primer cuento (1885) e incluso Bouquet (1886) que no se incluyen, como El pájaro azul (1886), en Azul, muestran ya claros indicios de estas inclinaciones, muy al estilo del art nouveau francés aunque con algunas huellas románticas. Aunque todavía no plenamente modernista, el ambiente exótico y el tema de la mujer y el amor en A las orillas del Rhin, y la floresta ornamental que simboliza a la mujer y la referencia mitológica (Venus, Minerva y Cibeles) en Bouquet son indicativos de la poética que aparecerá en Azul y se desarrollará plenamente en Prosas Profanas y Cantos de vida y esperanza. 
fin de encontrar la armonía entre el signo (el ideal) y el universo (las realidades). El arte y el artista se encargarán de redefinir los signos (la literatura, la pintura, la música, las mitologías).

En este contexto, Shakespeare le brinda a Darío el material propicio para su poética. Evidentemente, la mayoría de las obras que componen el corpus poético y cuentístico de Darío contiene aquellos rasgos y motivos formales y conceptuales que han hecho famosa la poética del escritor nicaragüense. Detenernos ante la aparición del hada Mab, particularmente en La copa de las hadas y El velo de la reina $M a b$, responde, en primer lugar, a la fecha de su publicación porque establece cronológicamente al hada Mab como adelantado patrón arquetípico, formal y conceptualmente desarrollado, de la poética dariana ${ }^{7}$. La aparición de Mab y el mundo de las hadas, en estas fechas de su primera etapa de formación y producción literaria, no es por motivos ornamentales ni únicamente supone un adelanto de la avalancha de motivos mitológicos, folklóricos y artísticos que dominarán su poética en todas sus etapas, sino que nos revela -en 1887, cuando todavía tenía veinte años- su talento y rigurosidad a la hora de elegir y desarrollar los motivos y símbolos que definirán su poética. En este breve estudio, proponemos investigar cómo Mab (mundo shakespeareano de las hadas) constituye un patrón de la poética dariana.

Las hadas aparecen en los romances medievales pero con el paso del tiempo se ven sustituidos por magos y brujas. Aun así, no desaparecen del todo y en muchas obras aparecen con ninfas, sátiros y otras criaturas de la tradición clásica. Con Shakespeare, vuelven a la literatura, ahora con más protagonismo, sobre todo después de su papel en Sueño de una noche de verano cuyo escenario es simultáneamente el bosque y lo que se dio en llamar el país de las hadas. A partir de esta reivindicación shakespeareana, las hadas se adjudican un lugar permanente, de mayor o menor importancia, en la literatura universal. A finales del siglo XIX, cuando surge la obra de Darío, las hadas vuelven a estar de moda hasta bien entrado el siglo $\mathrm{XX}^{8}$.

Desde que Shakespeare la introduce en su teatro, el hada Mab aparece en numerosas obras 9 como la figura mítica cuyos poderes -hacer que las personas tengan

${ }^{7}$ La copa de las hadas aparece en Santiago de Chile en diciembre de 1887. El velo de la reina Mab también se publica en Santiago de Chile el 2 de octubre de 1887 en La Época. Véase R. Darío, Cuentos Completos, edición y notas de Ernesto Sánchez Mejía y estudio preliminar de R. Lida, México, FCE, 1983; pp. 123-126; nota a pie de p. 123. Subsiguientes citas de todos los cuentos se harán de esta edición con la indicación $\mathrm{CC}$ y el número de página.

${ }^{8}$ Aparecen, entre otras, en las obras de Walter Scott (1771-1832), James Hogg (17701835), Lewis Carrol (1832-1898), E. Nesbit (1858-1924), Kipling (1865-1936), C.S. Lewis (1898-1963) y, evidentemente, en la de J. M. Barrie (1860-1937).

${ }^{9}$ Aunque Mab aparece en varias obras, incluso contemporáneas (lo último registrado es su rol como antagonista en la miniserie Merlín, 1989), las más citadas son The Entertain- 
visiones oníricas de sus más anhelados deseos- sirven al artista para conferir un ambiente mágico a la obra, o cierto dramatismo a una escena o a un personaje (Shakespeare) o para transmitir un mensaje moral o filosófico (Shelley). Su capacidad de revelar los deseos secretos de las personas la convierten en materia óptima para la creación imaginativa. Su razón de ser es precisamente lo que identifica a los modernistas: Mab está vinculada con el mundo de los sueños y los deseos y, en ese sentido, simboliza los anhelos más profundos del subconsciente, aquello desconocido e inalcanzable que señalaba $\mathrm{Paz}^{10}$. El hada Mab aparece por primera vez en la literatura en Romeo y Julieta. Puck ${ }^{11}$ también hace su debut en otra obra de Shakespeare, Sueño de una noche de verano. Anterior a estas apariciones, Mab y Puck aparecen en su entorno original, las leyendas y mitos europeos que nos informan de sus características: las hadas son criaturas mágicas y bellas, y habitan un mundo también bello, formado de una sucesión de alegres procesiones, sublimes banquetes con música -siempre descrita como mágica o celestial- como tela de fondo. Pero también poseen poderes mágicos con los que hacen el bien y el mal, sin pensar en las consecuencias. No están movidos por ningún sentido moral y más bien se comportan como niños, buscando el placer y la alegría inmediatos. En Sueño de una noche de verano, Oberón ${ }^{12}$ y Titania $^{13}$ se pelean por quien se queda con el bello

ment at Althorp de Ben Jonson (1572-1637), Nymphidia de Michael Drayton (1563-1637) y el polémico Queen Mab. A Philosophical Poem, de Shelley (1792-1822).

${ }^{10}$ La frecuentemente citada definición de Paz parece indicar a Darío particularmente: "¿Qué es ser moderno? Es salir de su casa, su patria, su lengua, en busca de algo indefinible e inalcanzable", en O. Paz, Los hijos del Limo, Barcelona, Seix Barral 1993; p. 131. Citas de esta obra se harán de esta edición, con la indicación LHDL y el número de página.

${ }^{11}$ También de etimología dudosa, aunque posiblemente germánica o celta, Puck refiere a un hada o espíritu pagano. Desde que Shakespeare le inmortalizara en Sueño de una noche de verano, Puck, también llamado Robin Goodfellow (apodo cuya primera referencia data de 1531, Diccionario Oxford de Inglés), refiere exclusivamente a ese hada alegre y travieso, que en la obra de Shakespeare hace las veces de bufón de Oberón, rey de las hadas. El apodo Robin Buen Chico también es utilizado por Darío en El linchamiento de Puck (Azul) y en Los regalos de Puck (1914).

${ }^{12}$ Oberón es rey de las hadas. Aparece primero en los romances franceses y como personaje del folklore alemán. Véase Dyer, T. F., Thiselton, Folk-lore of Shakespeare. Nueva York, Harper, 1884 (en Shakespere Online). Subsiguientes citas de este artículo se indicarán con Dyer 1884. Oberón aparecerá repetidamente en la obra de Darío en conexión con el lugar de las hadas, espacio de inspiración del ideal del artista.

${ }^{13}$ Es otro nombre de Mab, reina de las hadas. El nombre Titania es, al parecer, invención de Shakespeare. Dyer informa que, según Ritson (Fairy Mythology of Shakespeare), ningún otro escritor la llama así; Keightley (Fairy Mythology) opina que la elección del nombre es lógica dado que en aquella época las hadas ocupaban el mismo lugar que las ninfas de Diana (que también figura frecuentemente en Darío). Por tanto, es lógico que la reina de las hadas, que ocupa el mismo lugar que Diana, tenga su nombre, en este caso, Titania, el nombre que 
chico robado de un rey hindú, convertido en un juguete que ambos quieren poseer. Más tarde, cautivada por Bottom ${ }^{14}$, Titania entrega el chico a Oberón quien a su vez la libera de la influencia de la poción de amor y hacen las paces como dos niños amigos y no como amantes ${ }^{15}$.

Las hadas son criaturas de un mundo encantado que viven por el placer y la belleza. Este es el mundo que Shakespeare evoca en sus obras y es el mismo cuyo espíritu Darío busca invocar en la suya. En Darío, Mab primero aparece en El velo de la reina Mab y La copa de las hadas (ambos en 1887). El primer indicio de la influencia shakespeareana es el apelativo "reina" que no aparece en anteriores referencias al hada. En La copa de las hadas, Mab aparece con su "manto real" pero Darío también le atribuye la condición de diosa helénica ("reina divina", "gesto olímpico"). Esta fusión de distintas referencias mitológicas recurre continuamente, como veremos más adelante, y denota un aspecto fundamental de su poética. El título de reina indica a Shakespeare como fuente directa del Mab dariano aunque Raimundo Lida también señala la influencia de La dernière fée de Catulle Mendès en el cuento de Darío: "Unas pocas líneas de La dernière fée revelarán cuánto debe a la lectura de Mendès - no sólo a la de Shakespeare- el autor de El velo de la reina Mab y de El linchamiento de Puck" (CC: 54). Evidentemente, la influencia de Catulle Mèndes es un constante en la obra de Darío y, cronológicamente, la influencia posiblemente existiera en el caso de Puck dado que El linchamiento de Puck aparece en 1893 pero El velo de la reina Mab aparece en 1887, un año antes de la aparición del cuento de Mendès ${ }^{16}$. El propio Mendès está influido por Shakespeare y, en su cuento, Mab mantiene algunos rasgos formales (como el carro hecho de una cáscara de avellana) ya presentes en la descripción shakespeareana del hada. Evidentemente, el cuento francés tiene algunas nociones comunes, aunque algo modificadas, con el cuento de Darío. La carroza del hada Mab, en el cuento de Darío, es de una sola perla; en el cuento francés, es la propia Mab -aquí Oriana ${ }^{17}$ - la que se achica (para poder reposar en la mejilla de la joven) hasta quedar "ni más gruesa que una perla casi invisible". Darío expone la confrontación del artista con el mundo materialista; Catulle Mendès, la del amor con el mismo mundo materialista pero

Ovidio da a Diana en su Metamorfosis. En Romeo y Julieta, se le conoce por el más popular apelativo de reina Mab. Véase Dyer 1884.

${ }^{14}$ Como veremos más adelante, este personaje aparecerá en Dream (El Canto Errante) junto con Titania y el propio Shakespeare.

${ }^{15}$ Véase Dyer 1884.

${ }^{16}$ La dernière fée (La última hada) aparece dentro de la colección de cuentos apropiadamente titulada Les oiseaux bleus (Los pájaros azules), Paris, Victor Havard, 1888.

${ }^{17}$ Como Mab, Oriana también es de etimología dudosa. Refiere a la salida o el color del sol. De sus variantes, aparece Dorian (nombre del protagonista de la novela El retrato de Dorian Grey de Wilde). Oriana aparece como nombre del hada protagonista del libro infantil A Fada Oriana de la escritora portuguesa Sophia de Mello Breyner Andersen. 
señalando además el avance tecnológico como motivo de la aniquilación del ideal (el mundo de las hadas):

para que se pudiesen edificar casas, para abrir un paso a espantosas máquinas soplando vapores y llamas, han talado los árboles [...] llenando con piedras las grutas que accedían a vuestros misteriosos palacios de cristal, y todas las hadas han sucumbido en el desastre.

Unas líneas más adelante, cuando llega Oriana, buscando refugio, a la casa de los "petirrojos del muro florido de glicinas", encuentra colgado en el lugar de su nido "un trozo de loza blanca que atravesaba el hilo de una línea de telégrafo"18.

Como en Sueño de una noche de verano, en La copa de las hadas impera, sobre el mundo de las hadas, la alegría y la belleza: Shakespeare habla -en boca de Oberón- de "dances and delight" y Darío de "aquella región que era/ de la luz y la fortuna". Se advierte asimismo la musicalidad de las palabras en Shakespeare que Darío traspone a su poema, en aliteraciones como "islas de las rosas". También en El palacio del sol percibimos esa misma alegría cuando Mab le advierte a Berta "cuida de no beber tanto el néctar de la danza, y de no desvanecerte en las primeras rápidas alegrías.[...] Un minuto en el palacio del sol deja en los cuerpos y en las almas años de fuego" (CC: 109). Cuando las hadas, "por un extraño capricho", confeccionan una copa (La copa de las hadas), Mab es quien decide llenarla de "la felicidad completa". En la confección de la copa están presentes motivos darianos: "azucena", "polvo de nieve", "palidez de marfil", "trémulo suspiro/ de reflejos de zafiro", "luz cristalizada", son sustancias, casi todas, intangibles, y todas se dirigen a los sentidos. La copa simboliza la ilusión y el sueño. Las hadas tienen el poder de llenarla de los deseos anhelados por el hombre: ilusión, belleza, riqueza, corazón. La reina Mab manda poner "amor, delicia, verdad,/dicha, esplendor y riqueza,/ fe, poderío, belleza.../ ¡Toda la felicidad!...”. Los versos delatan ya el comienzo de un nuevo lenguaje y de imágenes exóticas que se imponen en Azul y llegarán a su auge en Prosas Profanas.

Otro motivo que invade la obra de Darío y que también es un constante en el mundo de las hadas es la presencia de flores y mariposas en el lugar habitado por las hadas, siempre rural (un bosque, una selva) y mágico. En la descripción que hace Oberón del lugar de reposo de Titania, prevalecen las imágenes de las flores:

Sé de un lindero donde crece el tomillo silvestre, donde se balancean las violetas y las primuláceas, doselado completamente por olorosas madreselvas, por fragantes rosas de almizcle y lindos escaramujos. Allí duerme Titania una parte de la

${ }^{18}$ La traducción de estos pasajes del cuento de Catulle Mendès son de José M. Ramos, en www.iesxunqueiral.com/mendes. 
noche reclinada al arrullo de esas flores, entre danzas y regocijos ${ }^{19}$.

En La copa de las hadas, el poeta se pregunta sobre el lugar donde están las hadas, "ifue en las islas de las rosas" o "el país de los sueños" donde hay "niños risueños / y enjambre de mariposas?". En El humo de la pipa, con la quinta bocanada de humo, el protagonista se encuentra en "una selva maravillosa" (CC: 191); una vez castigado por las hadas, advierte que "todo el bosque le hablaba" (CC: 192). Al comienzo de El linchamiento de Puck (1893), el narrador nos informa que "esto pasó en la selva de Brocelianda ${ }^{20 "}$ (CC: 267). Puck es perseguido por los "espíritus del bosque" (CC: 267) y "las rosas, los pájaros, los seres todos de la floresta, estaban contra el infeliz" (CC: 268). En El palacio del sol, Berta "erraba sin rumbo aquí, allá; y las flores estaban tristes de verla". La magia sucede cuando toca un lirio de donde sale "una hada, en su carro áureo y diminuto" (CC: 108). La tierra de las hadas constituye, entonces, un ambiente bello y mágico que Darío convertirá, como veremos más adelante, en el ideal de belleza en los momentos de contemplación e instantes fugaces de inspiración del artista.

En Ésta era una reina, el nombre de Mab figura entre los de las hadas madrinas de la Reina Amelia: “¿Gloriana? Quizás. O tal vez Viriana, o todas ellas, y a la cabeza de la tropa, Mab, fueron madrinas suyas" (CC: 252). Esta pieza presenta uno de aquellos casos donde difícilmente se puede diferenciar entre los artículos de Darío y sus cuentos. Raimundo Lida señala que "a menudo llegan a borrarse los límites del relato con la crónica, el rápido apunte descriptivo o el ensayo" (CC: 8). Y añade, "Sólo la presencia de cierto mínimo de acción es lo que nos mueve a incluir, entre sus cuentos, páginas como Ésta era una reina" (CC: 8). Ese "mínimo de acción" no es otra cosa que el ambiente de cuento de hadas que envuelve la crónica de las celebraciones que tuvieron lugar en Madrid en 1892 con motivo del cuarto centenario del descubrimiento de América. Como miembro de la delegación nicaragüense, Darío ve de cerca a los reyes de España y los de Portugal y la crónica gira en torno a la fascinación del poeta con la belleza de la reina Amelia de Portugal. Darío convierte la crónica en "un cuadro de féerie" (CC: 254) para transmitir a sus

${ }^{19}$ De la traducción electrónica en http://integrar.blue.edu.ar/wp; p. 15; "I know a bank where the wild thyme blows/ Where oxlips and the nodding violet grows,/ Quite overcanopied with luscious woodbine,/ With sweet musk-roses, and with eglentine/ There sleeps Titania sometime of the night,/ Lull'd in these flowers with dances and delight" (II. i); en W. Shakespeare, The Complete Works, edición e introducción de Peter Alexander, Londres y Glasgow, Collins, 1954, p.205. Citas de las obras de Shakespeare en inglés se harán de esta edición con la indicación TCW y el número de página.

${ }^{20}$ Broceliande no aparece como nombre del bosque encantado en las obras de Shakespeare pero sí en la literatura francesa desde el siglo XII. Nuevamente, Darío entremezcla sus fuentes, creando nuevas connotaciones que reinventan la simbología, ahora propiamente suya. 
lectoras ${ }^{21}$ la belleza de la princesa y la majestuosidad de la ocasión: “¿por qué Des Esseintes $^{22}$ no ha de ser para vosotras, elegantes lectoras de La Tribuna, algo así como uno de aquellos narradores que en los castillos medioevales distraían la atención de las castellanas..." ${ }^{23}$ (CC: 252). La reina de Portugal se convierte en "reina de un cuento azul" y "propia para prometida del príncipe de Trebizonda, o del príncipe de Camaralzamán" (CC: 254). La crónica se filtra de momentos propios de cuentos folklóricos o de hadas, hecho que el propio narrador no deja de señalar sistemáticamente: "palacio real, entre lacayos estirados, en un cuadro de féerie" (CC: 254), "las que venían tras ella, como sacadas de los cuentos, eran condesas regordetas..." (CC: 255). La parodia del cuento de hadas se cierra con la aparición de un amigo poeta que "evoca en mi memoria la figura de Ruy Blas" (CC: 255). La imagen del súbdito humilde (imagen ideal) secretamente enamorado de la reina, que el "amigo poeta" (imagen real) evoca, es la última de una secuencia de imágenes que se dirigen a la memoria cultural del lector. Nuevamente, Darío reinventa el arte ajeno para capturar y sintetizar sensaciones, plasmándolas en cuadros animados. En realidad, la accesibilidad de las referencias culturales no facilita la tarea de retomar los pasos de Darío y reconstruir la intertextualidad presente en su obra. No por la ambigüedad de las referencias sino por cómo y qué selecciona y combina de estas referencias. Las hadas, Las mil y una noches, Ruy Blas o el idolatrado Lohengrin, la literatura del parnaso, de Cervantes y de Shakespeare, entre otros, se entremezclan constantemente para evocar el ideal modernista en la totalidad de la obra dariana.

La técnica de dirigirse a sus lectores no solamente aparece en cuentos-crónica como Ésta era una reina. Es un aspecto formal que se repite frecuentemente y que Darío adopta de los cuentos de hadas y los folklóricos. En El palacio del sol, cuando estamos a punto de ver aparecer mágicamente a Mab, salida del "cáliz" (otra palabra favorita del autor que aparece sistemáticamente con las flores) de la flor que Berta acaba de tocar, el contrapunto de realismo lo pone el narrador cuando se dirige a los lectores con esta interrupción: "No bien había... - sí, un cuento de hadas, señoras mías, pero ya veréis sus aplicaciones en una querida realidad" (CC: 106). Y en vez de suspenderse la ilusión de fantasía, se hace más auténtica. Las explicaciones fantásticas que siguen (de cómo se cura Berta detrás de visitar el palacio del sol) cobran la misma autenticidad y atracción que poseen los cuentos de hadas o las

${ }^{21}$ Raimundo Lida nos informa que el cuento se publica en Buenos Aires, en la sección dariana Mensajes de la tarde de La Tribuna, un 30 de septiembre de 1893 (CC: 252).

${ }^{22}$ Durante un tiempo (del 7 de septiembre de 1893 al 28 de febrero de 1894, según nos informa Raimundo Lida, CC: 252), Darío firmaba sus Mensajes con el seudónimo de Des Esseintes, el protagonista de la novela $\dot{A}$ rebours (1884) de J.K. Kuysmans.

${ }^{23}$ Parte del párrafo que Darío dirige a los lectores de su sección (Mensajes de la tarde) y que precede el cuento, que en esta primera publicación aparece bajo el título de La reina Amelia de Portugal (CC: 252). 
leyendas.

Otro recurso típicamente dariano, que también figura magistralmente en el discurso de Mercutio (Romeo y Julieta) sobre el hada Mab, es la descripción gráfica del hada y su carroza. En realidad, este recurso es uno de los más prominentes e influyentes de su poética. En más de una ocasión, Darío expresa su admiración por los escritores franceses y, en Historia de mis libros, propone "la aplicación de su manera de adjetivar" (PE: 200). Belmás, por otra parte, refiere al trascendental estudio de F. Contreras donde el autor señala "no solamente la etiología francesa de Azul, sino también la inglesa, a través de Shakespeare y de Shelley"24. Como habíamos señalado, Darío expresó (en Historia de mis libros) su fascinación por el estilo de Shakespeare, que le lleva a realizar sus primeras poemas en prosa donde tiene como objetivo perseguir "el ritmo y la sonoridad verbales" y realizar la misma "transposición musical" del dramaturgo inglés. Describiendo la poética de Darío, Contreras emplea casi las mismas palabras que Darío (al referirse a la influencia de los franceses y de Shakespeare): "la riqueza de la imagen, la novedad de la adjetivación, el ritmo exterior e interno, la selección del vocabulario y la ligereza de la frase dan al estilo una expresión, una armonía, un esplendor, un matiz insólitos en nuestra lengua" 25 . Séase por la influencia de los franceses o por la inspiración shakespeareana, Darío recupera esa forma de adjetivar, intercalando elementos y artificios de otras formas artísticas, sobre todo de las artes plásticas, en su escritura, desarrollándolos para producir un recurso formal que, despojado de sus connotaciones modernistas, evolucionará en la imagen vanguardista. Un ejemplo lo encontramos en El palacio del sol, en la imagen gráfica -y en este caso humorística- que proyecta el narrador a la hora de describir la reacción de todos al ver recuperada a Berta: "todos, la mamá, la prima, los criados, pusieron la boca en forma de O" (CC: 109). Esta "O" vuelve a aparecer en el poema, todavía modernista e incluso dariana ${ }^{26}$, de "Avestruz" (Los heraldos negros, 1919) de Vallejo pero con connotaciones más sombríos: "mañana que no tenga yo a quién volver los ojos,/cuando abra su gran $\mathrm{O}$ de burla el ataúd"27.

En Shakespeare, la imagen gráfica se presenta en la metáfora que elige el dramaturgo para describir el minúsculo tamaño del hada Mab: "es tan pequeña como el

${ }^{24}$ A. Oliver Belmás, Este otro Rubén Darío. Barcelona: Aedos 1960; p. 409. Citas de este libro se indicarán con Belmás y el número de página.

${ }^{25}$ Francisco Contreras, Rubén Darío, su vida y su obra. 1930, pp.172-73, citado por Belmás (Belmás: 409).

26 “domina en varios poemas todavía un estilo modernista bastante trasnochado en el que es patente la influencia de Darío y, sobre todo, de Herrera y Reissig, o motivos y marchamos del simbolismo francés", Américo Castro en su introducción a C. Vallejo, Obra poética completa, Madrid, Alianza 1994, p.10. Citas se harán de esta edición con la indicación OPC y el número de página.

${ }^{27} \mathrm{OPC}: 67$. 
ágata que brilla en el anillo de un regidor" ${ }^{28}$. Sigue una descripción detallada de su carroza que refleja la delicadeza, la finura y la magia del hada:

Su carroza va arrastrada por caballos leves como átomos, y sus radios son patas de tarántula, las correas son de gusano de seda, los frenos de rayos de luna; huesos de grillo e hilo de araña forman el látigo; y un mosquito de oscura librea, dos veces más pequeño que el insecto que la aguja sutil extrae del dedo de ociosa dama, guía el espléndido equipaje. Una cáscara de avellana forma el coche elaborado por la ardilla, eterna carpintera de las hadas. (DDGS: 175)

Estas imágenes inspiran la descripción, más escueta pero no por eso menos gráfica, de la aparición del hada en El palacio del sol ("en un carro áureo y diminuto, vestida de hilos brillantísimos e impalpables, con su aderezo de rocío, su diadema de perlas y su varita de plata", "la concha del carro de oro [...] holgada sobre el ala de un cisne a flor de agua", CC:108), y en El velo de la reina Mab: "La reina Mab, en su carro hecho de una sola perla, tirado por cuatro coleópteros de petos dorados y alas de pedrería, caminando sobre un rayo de sol, se coló por la ventana de una boardilla" (CC: 123). La cáscara de avellana se convierte en "oro", "concha del carro de oro" y "una sola perla", manteniendo la delicada minuciosidad del hada pero sustituyendo la avellana por la más ostentosa "concha" de oro o "perla", joyas mucho más afines a la belleza anhelada por la nueva estética. Los tenebrosos "rayos de luna" propicios para la magia y los engaños, se convierten en "rayos de sol", recalcando la imagen optimista del hada que visita a los soñadores para darles alegrías. La misma alegría y luminosidad se advierte en El palacio del sol, primeramente en el título, dado que refiere al lugar de las hadas ("un lindo palacio encantado, donde parecía sentirse el sol en el ambiente. ¡Oh, qué luz, qué incendios!”, CC: 109) y, luego, en la descripción del momento en el que Mab (que aquí figura simplemente como el hada de los sueños) lleva a Berta en su carro: "Y las flores, y el fauno orgulloso, la luz del día, vieron cómo en el carro del hada iba por el viento, plácida y sonriendo al sol, Berta...” (CC: 108).

${ }^{28}$ En Dramas de Guillermo Shakespeaere. El Mercader de Venecia, Macbeth, Romeo y Julieta, Otelo; traducción de Marcelino Menéndez Pelayo, Barcelona, 1881, p. 175. Subsiguientes citas se harán de esta edición con la indicación DDGS y el número de página. "In shape no bigger than an agate-stone /On the fore-finger of an alderman, /Drawn with a team of little atomies/ Athwart men's noses as they lie asleep; Her waggon-spokes made of long spinners' legs;/ The cover, of the wings of grasshoppers;/ Her traces, of the smallest spider's Web;/ Her collars of the moonshine's wat'ry beams;/ Her whip, of cricket's bone;/ the lash, of film;/ Her waggoner, a small grey-coated gnat,/ Not half so big as a round little worm/ Prick'd from the lazy finger of a maid./ Her chariot is an empty hazel-nut,/ Made by the joiner squirrel or old grub,/Time out o' mind the fairies' coachmakers./ And in this state she gallops night by night" (I.iv) (TCW: 908). 
En El velo de la reina Mab, Darío explaya secuencias descriptivas, nunca meramente decorativas dado que realizan, en conjunto, la función de sugerir el estado de ánimo del artista. Las imágenes apelan, primeramente, al sentido visual del lector. Darío crea imágenes con una selección detallista de las palabras que se acoplan a la esencia y la belleza de cada arte: "la gran lucha de mis sueños de mármol", "Venus, que muestra su desnudez bajo el plafón color de cielo" "los desnudos en que la ninfa huye y el fauno tiende los brazos", "he pintado el torso de Diana y el rostro de la Madona", "he adulado a la luz como a una amada, y la he abrazado como a una querida" (CC: 124), "y para hallar consonantes, los busco en dos bocas que se juntan; y estalla el beso, y escribo la estrofa" (CC: 125). La combinación armónica de vocablos también se dirige a los demás sentidos. El velo de Mab es "como formado de suspiros, o de miradas de ángeles rubios y pensativos" (CC: 126), el músico declara que "la luz vibrante es himno" y el poeta, que "tengo el verso que es de miel", "yo soy el anáfora del celeste perfume" (CC: 125). La sinestesia, una influencia directa de Catulle Mèndes ${ }^{29}$ y el parnaso francés, es un recurso que Darío adoptará para realizar combinaciones inesperadas de metáforas y símiles innovadores y, por tanto, efectivos. Es una técnica que tiene el mismo efecto que la intertextualidad, cuando Darío elige evocar al hada Mab/Titania shakespeareana o al saturno goyesco o al ya citado cisne wagneriano vuelto dariano. La sinestesia es la interpretación sensual de la metáfora y el símil, y la intertextualidad es un (re)lectura de mitos, cuadros u obras literarias, reorganizados de una forma que nos obliga a cambiar nuestra perspectiva del mundo ${ }^{30}$.

Las hadas se integran tempranamente como elementos formales constantes en la obra de Darío y Mab se sitúa como un patrón inicial de su poética. Llegamos ahora a la relación de Mab con algunos conceptos de la obra de Darío. En primer lugar, habría que señalar que Mab se vincula con las ideas que más atraen a Darío debido no solamente a su aspecto formal (delicadeza, minuciosidad) sino a sus poderes mágicos. En algunas ocasiones, la manifestación de estos poderes no supone más que la creación del ambiente mágico: en El palacio del sol, por ejemplo, Mab hace empequeñecer a Berta para que pueda montar en su carro: "Y como si Berta se hubiese empequeñecido, de tal modo cupo en la concha del carro de oro" (CC:

${ }^{29}$ En un breve artículo sobre Darío, O. Buljevic acertadamente señala los comentarios de Darío sobre la sinestesia en el breve texto "De Catulle Mendès. Parnasianos y decadentes" (1888): "nuestro poeta defenderá las relaciones entre el "arte de la palabra" y otras artes y sensibilidades (la pintura, la luz y el color, por ejemplo). En estos juegos sinestésicos, en la integración entre los sentidos y las artes, lo que emerge es una visión estética y holística del mundo así como una percepción nueva, virginal, impresionista, pictórica, que va a contestar en la práctica la captación realista-positivista", en C. O. Buljevic, "Origen y contexto del azul de Rubén Darío", publicado en magazinemodernista.com, en abril del 2012.

30 "El modernismo se inició como una búsqueda del ritmo verbal y culminó en una visión del universo como ritmo" (LHDL: 136). 
108). En otras, los poderes mágicos se vinculan con temas más serios (el castigo, la fatalidad, la muerte) o, evidentemente, más afines al tema modernista del ideal del arte. En La copa de las hadas, el poeta se limita a reenumerar las hadas presentes, señalando sus poderes "Las que tienen prisioneros/ a los silfos ${ }^{31}$ de la luz" o "las que hienden el aire/ con su varita de plata", de forma ligera y alegre. Pero lo mismo que tienen el poder de dar "la felicidad completa" son capaces de los castigos más crueles: en El humo de la Pipa, las hadas se debaten entre dejarle ciego al protagonista, convertirlo en piedra o árbol, azotarle, o que "Sufra la suerte del príncipe Camaralzamán. - Pongámosle prisionero en el fondo del mar" (CC: 191). Como en otras ocasiones, Darío fusiona sus fuentes de inspiración, haciendo aparecer al hada Mab con una figura de Las mil y una noches. En Pequeño poema infantil (1914), aparece Carabosa, el hada de la "profecía odiosa", jorobaza, fea "como son/feos toda mala idea/ y todo mal corazón". En El linchamiento de Puck, condenado éste a la horca, vuelve a aparecer el hada cruel: "No había cuerda para ahorcarle; pero el hada cruel que dio a Byron la cojera ${ }^{32}$, se arrancó un cabello cano, y con él colgó a Puck de un laurel casi seco" (CC: 268). Puck sobrevive porque "un hada caritativa [...] con las tijeras con que cortó los vestidos de Cenicienta, cortó la cuerda de Puck" (CC: 268). En el cuento original, cuando la madrastra cruel intenta asfixiar a Cenicienta con las cuerdas de su vestido, son los siete enanos quienes la salvan pero Darío lo atribuye a un hada. Nuevamente, advertimos el cruce de fuentes literarias: aparecen, uno tras otro, Mab, Puck, hada cruel, hada caritativa (mitología anglosajona y germana), Cenicienta (cuentos de hada), Shakespeare "celeste poeta" y Byron. Esta intertextualidad, que ya hemos señalado más veces, podría considerarse un artefacto formal que refleja el ideal de armonía y unidad que buscaba Darío ${ }^{33}$. En $E l$ palacio del sol, Mab salva a la joven Berta de su clorosis al llevarla al palacio del

${ }^{31}$ De origen galo, también son seres fantásticos, espíritus elementales del aire. Zuleta también los define como espíritus elementales del aire pero añade "de los cabalistas" (PP: 205)

${ }^{32}$ Defecto físico que se atribuye a una mala intervención durante el parto. El detalle es mínimo pero Darío lo incorpora, recalcando su auténtica dedicación a la reconstrucción de la realidad a través de una perspectiva fantaseada.

${ }^{33}$ Este aspecto formal es mucho menos complejo que el conceptual esotérico encontrado en el juego numérico de algunas de sus obras o en algunas figuras míticas como Pan que aparece en más de un cuento y poema del autor. R. Oviedo señala a Pan como uno de los mitos favoritos de Darío "identificado con el Todo de los ocultistas", en Darío, Cantos de vida y esperanza, edición de R. Oviedo Pérez de Tudela, Barcelona, De Bolsillo, 2004, nota 6, p. 43. Señala, además, cómo "Darío relaciona el concepto de Pan, el misterio del chorro de la fuente y el pitagorismo que nos habla de la armonía de las esferas" (nota 83, p. 78). Claros indicios de este ocultismo impregna muchos de sus poemas. Véase, además, C.L. Jrade, Rubén Dario o la búsqueda romántica de la unidad. El recurso modernista a la tradición esotérica. México, FCE, 1970. 
sol. En El humo de la pipa, el hada cruel decide que el castigo adecuado del soñador es vivir sin amor. Mab se compadece de él y le da un amuleto "en que está grabado por un genio la gran palabra. Leí: esperanza" (CC: 191). Lo mismo sucede en El velo de la reina Mab cuando el hada Mab se compadece de los artistas y les da la esperanza y "el diablillo de la vanidad" (CC: 126). Aunque el cuento es una recreación del hada shakespeareano, la carga simbólica y emotiva del hada Mab en Romeo y Julieta es muy distinta a la dariana. Con su discurso sobre Mab, Mercutio se burla de las ilusiones y los sueños engañadores del hombre. Mercutio es un personaje realista cuya actitud se contrapone a la visión idealista de Romeo y Teobaldo; es la voz de la razón y, con sus comentarios despectivos sobre el hada Mab, intenta convencer a Romeo de la banalidad de los sueños:

En ese carro discurre de noche y día por cabezas enamoradas, y les hace concebir vanos deseos, y anda por las cabezas de los cortesanos, y les inspira vanas cortesías. Corre por los dedos de los abogados, y sueñan con procesos. Recorre los labios de las damas, y sueñan con besos. Anda por las narices de los pretendientes, y sueñan que han alcanzado un empleo. Azota con la punta de un rabo de puerco las orejas del cura, produciendo en ellas sabroso cosquilleo, indicio cierto de beneficio o canonjía cercana. Se adhiere al cuello del soldado, y le hace soñar que vence y triunfa de sus enemigos y los degüella con su truculento acero toledano, hasta que oyendo los sones del cercano tambor, se despierta sobresaltado, reza un padrenuestro, y vuelve a dormirse. La reina Mab es quien enreda de noche las crines de los caballos, y enmaraña el pelo de los duendes, e infecta el lecho de la cándida virgen, y despierta en ella por primera vez impuros pensamientos. (DDGS: 175-176)

La reina Mab shakespeareana ofrece sueños que no responden a lo más noble del ser humano y más bien sirven para impulsar sus vicios (avaricia, lujuria, violencia, prepotencia). Evidentemente, esta perspectiva es opuesta a la modernista de Darío que ve en el hada de los sueños la proyección del ideal imposible. En El velo de la reina Mab, el hada representa la esperanza para los cuatro artistas. En Romeo y Julieta, Mercutio no cree en un mundo ideal y percibe la hipocresía de unos ideales que encubren deseos innobles. En ese sentido, su referencia al hada Mab como reina puede conllevar el otro significado del vocablo -más común en la Inglaterra isabelina- denotando "prostituta" ${ }^{34}$. Se crea -intencionalmente o no- una conexión entre el mundo mágico de las hadas y las connotaciones más negativas del vocablo "re-

34 De etimologías distintas, los dos vocablos “queen" y "quean" se pronuncian de la misma forma, pero la primera refiere a la reina mientras que la segunda, que significa "musa" o "quen" ("comadrona"), llegó a referirse, a partir del siglo XI, a "prostituta". La frecuente confusión entre las dos palabras dio lugar a la difusión del sentido peyorativo en asociación con el vocablo reina, el más popular de los dos. 
ina". A través de Mab, Shakespeare presenta los sueños como aspecto débil y avaro del ser humano. En El velo de la reina Mab, el hada realiza el mismo papel de portadora de sueños pero Darío le confiere una imagen positiva. En vez de una historia de amor imposible en Verona del siglo XVI, el cuento de Darío es una historia de comienzos y creaciones, concretamente, la creación del temperamento bohemio del artista. En un tiempo lejano y fantástico "las hadas habían repartido sus dones a los mortales" (CC: 123) y cada mortal se le adjudica su lugar en el mundo. A los cuatro hombres en la buhardilla les tocó en suerte el gusanillo de la creatividad artística. El discurso de Mercutio se ve sustituido por los cuatro discursos de los artistas (escultor, pintor, músico y poeta) que, uno por uno, van lamentando su miseria y la imposibilidad de un porvenir esperanzador. Mab aparece para salvarles. En esencia, es la misma reina Mab que engaña a los soñadores pero aquí la perspectiva modernista la eleva a rango de salvadora: Mab les envuelve en el velo azul de los sueños. Con esto, les obsequia con la esperanza y, sobre todo, la vanidad necesarias para todo artista: "cesaron de estar tristes porque penetró en su pecho la esperanza, y en su cabeza el sol alegre, con el diablillo de la vanidad, que consuela en sus profundas decepciones a los pobres artistas" (CC: 126). Darío introduce cambios en los poderes de Mab que ahora no revela los sueños ni engaña con visiones oníricas; realiza un acto mágico, ofreciendo a los artistas la vanidad "que consuela" ante la pobreza material a que están sometidos por la sociedad. Darío manipula la figura del hada para instaurar un ambiente mágico y bello (que contrasta con el de los cuatro artistas "flacos, barbudos e impertinentes" CC: 123) y aprovecha sus poderes para la creación del temperamento artístico, el auténtico bohemio con su clásica imagen de hombre flaco, desaseado, ensimismado, en su buhardilla ("Cabellos largos en la buhardilla,/ noches de insomnio al blancor del invierno" ${ }^{\text {35 }}$ ). Conceptual y formalmente, el modernismo está servido: Darío crea la imagen a la vez que crea el concepto. El proceso formativo de su estética consiste en la elección de Mab como material para su cuento, hecho que confirma la adherencia de Darío a los dos ejes monitores del modernismo: el simbolismo y el parnasianismo. Mab realiza una doble función como el símbolo (el sueño) y lo simbolizado (el ideal). El contenido conceptual del cuento no existe o existe únicamente como reflejo de la forma; el concepto es la forma y viceversa. El parnasianismo está en la presentación del artista como el renegado por la sociedad; nuevamente el artista víctima que aparece en El pájaro azul. Darío no se desprende del todo de la influencia romántica y los artistas que protagonizan El velo de la reina Mab expresan su aguda sensibilidad ante una sociedad que les menosprecia. Con la esperanza y la vanidad que Mab les obse-

${ }^{35}$ Proyección de la imagen del artista en Balada en honor de las musas de carne y hueso (El canto errante), en R. Darío, Poesía, introducción y selección de Jorge Campos, Madrid, Alianza, 1977, p. 104. Siguientes citas de este libro se indicarán con Poesía y el número de página. 
quia, conseguirán el éxito que merecen pero fuera de la realidad mediocre que les rodea. El artista de Darío buscará su éxito en una realidad maravillosa y mítica. Darío, como los autores del parnaso, hace uso de la mitología (Mab) en su búsqueda del ideal de belleza artística: sólo en el sueño azul de Mab puede el artista crear su obra de arte.

Mab vuelve a aparecer como símbolo del ideal del arte, que sólo existe en la mente y el ojo del artista, en dos ocasiones más en Azul: "El ideal" y "Autumnal". En ambos, ya no es el tiempo de comienzos, cuando las hadas repartían los dones a los mortales (El Velo de la reina Mab). Ahora, Mab aparece directamente en los momentos de contemplación (Autumnal) o inspiración (El ideal) del artista. Mab se presenta en conexión con el proceso creativo como símbolo del ideal anhelado pero imposible. En El ideal, el pintor encuentra, por un instante, su ideal del arte: "Era una estatua antigua con un alma que se asomaba a los ojos, ojos angelicales, todos ternura, todos cielo azul, todos enigma" (CC: 122). El ideal del arte se identifica y se une al ideal del amor: "una torre de marfil, una flor mística, una estrella a quien enamorar... Pasó, la vi como quien viera un alba, huyente, rápida, implacable". La quimera, que sólo existe "en el fondo de mi cerebro", es la inspiración que le brinda Mab. Aquí, Mab no aparece con su nombre sino a través de las referencias ya señaladas en El velo de la reina Mab o El palacio del sol. El pintor sólo refiere al "vestido luminoso de la hada" y "la estrella de su diadema", referencias simbólicas del hada que le inspira al pintor "un rostro de mujer, un sueño azul". En el poema $A u$ tumnal, Mab aparece en diálogo con el poeta. Mab llega al poeta en un momento contemplativo que Darío expresa en una imagen gráfica con que abre y cierra el poema: empieza con "yerran nubes tranquilas/en el azul; en las ardientes manos/se posan las cabezas pensativas" ${ }^{\text {36 }}$ y cierra con una modificación a primera persona: “¿Más?... - dijo el hada. Y yo tenía entonces/ clavadas las pupilas/ en el azul, y en mis ardientes manos/ se posó mi cabeza pensativa..." (Azul: 154). Cuando el poeta le pide inspiración al hada, Darío describe la respuesta con palabras ya familiares, referentes reconocibles del hada y su magia: "con el acento/con que me hablaría un arpa", "divino idioma de esperanza" "sed del ideal" (Azul: 153). La sistemática repetición de ciertas palabras e imágenes en referencia a Mab delatan su evolución como símbolo dariano que ahora se identifica con la imagen del poeta en estado pensativo o momentos de inspiración. Mab transporta al poeta al lugar encantado de las hadas ("jardín de oro") donde vislumbra la esperanza y la inspiración a través de imágenes de la aurora, las flores y el viento que trae "músicas nunca oídas". El velo de Mab aparece en la penúltima estrofa, cuando sus poderes mágicos le ofrece al poeta la musa ("un bello rostro de mujer") que necesita para crear su arte. Pero Mab es símbolo del ideal imposible y el poeta en seguida lo exclama: “¡Oh; nunca,/ Pié-

${ }^{36}$ R. Darío, Azul, Madrid, ALBA, 1997, p. 152. Citas de los poemas de esta obra se harán de esta edición con la indicación Azul y el número de página. 
rides, diréis las sacras dichas/ que en el alma sintiera!" (Azul: 154).

En La muerte de Salomé (1891), vuelve a aparecer Mab, con otras hadas, como el contrapunto a la Historia. Mab, nuevamente está unida al poeta. El narrador nos informa que la Historia "a veces no está en lo cierto" y afirma que "la leyenda en ocasiones es verdadera, y las hadas mismas confiesan, en sus intimidades con algunos poetas, que mucho hay falseado en todo lo que se refiere a Mab, a Titania, a Broceliande" (CC: 223). Nuevamente, Mab acompaña al poeta, es su cómplice y es inspiradora de su ideal o su visión del mundo. Aquí, Mab está al lado del poeta ante las falsificaciones de la Historia. La introducción de Mab es el preámbulo a su propia versión del cuento bíblico de Salomé. En esta ocasión, el arte ("artífice romano") se une a la justicia ("un pretor") para matar a "la princesa encantadora y cruel" con un collar en forma de serpiente de oro.

En Prosas Profanas, Mab ya es parte del repertorio de símbolos darianos conectados al arte y al artista. En Del campo, el poeta se despide de Buenos Aires; nuevamente, su cómplice es Mab, que a partir de ahora aparecerá como Titania:

hoy en tu verde triunfo tendrán mis sueños vida,

Respiraré tu aliento, me bañaré en tu sol.

[...]

Un pájaro poeta, rumia en su buche versos;

Chismoso y petulante, charlando va un gorrión;

Las plantas trepadoras conversan de política;

Las rosas y los lirios, del arte y del amor

Rigiendo su cuadriga de mágicas libélulas

de sueños millonario, pasa el travieso Puck;

y, espléndida Sportwoman, en su celeste carro,

la emperatriz Titania seguida de Oberón (PP: 100-101)

Junto con Oberón y Puck, Titania representa el punto de mira -el ideal- del poeta. Las hadas invocan su personal visión, la visión que él sueña, la que le permite "poetizar" sobre lugares, personajes y arte.

En Dream (El Canto Errante), se reafirma la conexión hadas-poeta en unos versos que proyectan sucesivas imágenes del sueño del poeta. Pasean por el sueño figuras literarias admiradas por Darío y, algunos de ellos (sobre todo Hugo y Verlaine y, en menos grado, Beardsley), fuentes de su inspiración. El sueño comienza con la imagen de Bottom "sentimental" y Titania "toda es sonrisa", con lo cual el poeta revela, nuevamente, el espacio de su ideal (sueño) de inspiración: "la floresta" idílica de Shakespeare. (Poesía: 99).

En otros dos poemas de Prosas Profanas, aparece el leitmotiv del hada aunque no particularmente Mab/Titania. En Cosas del Cid (que se añade a la segunda edición de Prosas Profanas, Paris-1901), la joven que sale del bosque a recibir al Cid es descrita a través de dos imágenes (el hada y la primavera) seguida la una a la otra de modo que la imagen del hada ya evoca una particular visión de "divina Primave- 
ra": "Una niña que fuera un hada, o que surgiera/ encarnación de la divina Primavera" (PP: 158). En La Anciana, el poeta nuevamente conversa con el hada, que aquí es parte de la "mágica armonía" de la naturaleza. El hada revela al poeta cómo las rosas secas le dan juventud y ella, a su vez, les da "vida y vuelo":

Y transformóse en una princesa perfumada,

Y en el aire sutil, de los dedos del hada

Voló la rosa seca como una mariposa (PP: 170)

Esta interpretación mágica de la armonía del universo aparece en otras obras de Darío. En Dilucidaciones (El canto errante), Darío reflexiona sobre su obra y declara que "he meditado ante el problema de la existencia y he procurado ir hacia la más alta idealidad. He expresado lo expresable de mi alma y he querido penetrar en el alma de los demás y hundirme en la vasta alma universal" (PE: 134-135). En Pequeño poema infantil, percibimos nuevamente esa intención de armonía en la compaginación del mundo fantástico y el místico. En este poema Mab y las demás hadas se llaman directamente "hadas paganas" en virtud de su comparación con la Virgen María "Reina más que todas ellas:/ la Reina de las Estrellas,/ la dulce Virgen María" que ahora se encargará de proteger a la niña a quien habla el poeta: "que perfume tus anhelos/ su nombre que el mal destierra,/pues ella aroma los cielos/ y la tierra". Aquí también, Mab, las demás hadas, Broceliande y Shakespeare se fusionan con figuras religiosas e históricas; una vez más, la búsqueda de redes subyacentes que puedan definir la armonía y la unidad del universo.

Hacia el final (1912-1916), desaparecen casi todos los símbolos de su arte y de su amor al arte. Las hadas no se mencionan pero sí el mundo que representan (la quimera del ideal): en Pasa y olvida (1916), el sueño del poeta se presenta como "un mal". La voz del Canto Errante vuelve a surgir en una agridulce resignación a la imposibilidad de encontrar "ese país incógnito que sueñas" (Poesía: 139). El poeta parece dirigirse al artista, al modernista "peregrino" que jamás alcanza su ideal, aquí no solamente en lo que refiere a su arte sino a la anhelada armonía.

Nuestro propósito ha sido examinar el papel del hada Mab y su lugar dentro de la simbología dariana y constatar que es, efectivamente, uno de los primeros patrones de su poética. De Azul, Darío dice que "es una obra, repito, que contiene la flor de mi juventud, que exterioriza la íntima poesía de las primeras ilusiones y que está impregnada de amor al arte y de amor al amor" (PE: 107). Cándida pasión por el arte, pasión por la belleza, con huellas del rococó que impregna la literatura del parnaso, instinto de poeta...todo converge en el momento de creatividad artística de Darío y formula su poética. Como pocos, Darío ha logrado reinterpretar una vasta colección de fuentes artísticas y moldearla en una poética auténticamente suya. Descubre el mundo de las hadas y elige a Mab como el cómplice idóneo del artista. Tanto su imagen como su referente conceptual corresponden a la belleza y el placer del arte. Mab conlleva los aspectos formales que seguirán definiendo la poética de 
Darío, incluso en sus obras más tardías. La musicalidad del lenguaje, las imágenes gráficas y la sinestesia persisten en Prosas Profanas, Cantos de vida y esperanza y El canto errante. Además, estos elementos formales supondrán un paso hacia la vanguardia. A nivel conceptual, Darío desarrolla el simbolismo de la figura de Mab, enfocando sus poderes mágicos (hacer soñar) en la inspiración del ideal soñado por el artista pero jamás alcanzado. Mab, que en Shakespeare simboliza el engaño de los sueños, en Darío es la inspiración y la esperanza sin las que el artista no puede existir. Mab cobra nuevos significados como símbolo del ideal imposible. Darío la vincula directamente con el artista, convirtiéndola en su confidente ante la mediocridad de la realidad. Como Venus o Shehrazada, Mab aparece en Darío vinculada al amor y a la mujer -a su vez vinculados al arte- aunque también le ha servido a Darío para la anécdota, la revisión de la Historia o la crónica fantaseada. La Mab de Shakespeare, como Venus, Orfeo o el cisne de Wagner, adquiere un simbolismo nuevo dentro de la poética de Darío. 